\title{
Bank Lending Decisions Using Projections: A Case-study Approach
}

Evangelos P. Koumanakos, (Email:koumanak@upatras.gr, National Bank of Greece, Greece Osamah M. Al-Khazali, American University of Sharjah, UAE

\begin{abstract}
This paper, by emphasizing on the process and dynamics of bank corporate credit decisions, presents a description of an introductory case-study suitable for an undergraduate/MSc banking or business finance course. The case exists in two parts and is designed for instructors to be able to use only those parts which they consider appropriate to their objectives and time considerations. In two or three seventy-five minute classes-depending on the parts of the case utilized and the time allowed for student interaction-instructors can have students explore the factors that influence the lending decision and focus on the interpretation of the mechanical process used in constructing projected financial statements for the identification of the actual borrowing needs of a specific company.
\end{abstract}

\section{INTRODUCTION}

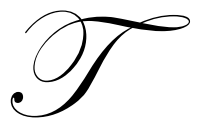

he increasing globalisation of the contemporary banking industry highlights the key importance of common problems and challenges that banks are facing in their core area of activities. One of the most crucial of those banking activities is the successful assessment of the level of credit risk involved in loan applications. There is a considerable amount of literature on credit risk and a number of sophisticated models have been developed to measure credit risk ${ }^{1}$. However, there is relatively little known on the way that banks utilise those models or other analytical tools in real life for assessing loan applications from corporate clients. We document that the corporate lending process have changed significantly over the last years and this has an effect on the quality of the balance sheet of the banks and their profitability. Banks, in general, have been providing a growing level of corporate credit but at the same time, they experience reduced loses from their non-working corporate loans. This is mainly a result of the reforms in the corporate credit decision process.

Companies borrow money from banks for many reasons and there is a risk associated with every borrowing transaction for both the borrower and the lender. Some of the reasons for borrowing money are intuitively less risky than others. For example generally there is less risk in lending money on a short term basis than on a longer term basis.

Perhaps the commonest borrowing reason is that a company borrows in order to meet its ongoing operating expenses until it can convert a specific asset into cash. Other reasons could be: to finance fixed assets or inventory required to produce output that is converted to sales and then cash; to finance a change in the firm's ownership; or to finance survival until the firm can be turned around.

However, a company's stated reason for borrowing may not always be the real reason. This does not always mean that the borrower isn't being honest in his request to borrow funds. Simply, what appears to the company to be the primary reason may in fact be the secondary reason. For example, a company may approach a lender for additional borrowings to make a large inventory purchase. That is the immediate reason for the new funds. Yet upon examination, the lender may find that the company is having severe profitability problems that are draining away cash.

\footnotetext{
${ }^{1}$ For example, see Merton (1974); Longstaff and Schwartz (1995); Duffee and Zhou (1999); Crouhy, Galai and Mark (2001); Jarrow and Yu (2001); and Barnhill and Maxwell (2002).
} 
That drain in turn forces the company to seek outside funds for the inventory purchase. If the profitability problems did not exist the company might well be able to fund the inventory purchase from internal cash sources. Generally, the level of borrowing in a given company would tend to remain fairly flat so long as company operations remain stable. If the company is not growing it would have little reason to borrow additional amounts to hold receivables and inventory. The same would tend to hold with respect to fixed assets. In a stable environment a borrower would be replacing fixed assets rather than adding to property, plant and equipment and as a matter of fact the company's longer term borrowing needs for that purpose would tend to be minor.

In this workbook, by focusing at a prospective borrower (PAPERBASIS S.A.) with a certain loan application, we intend to shed light onto the banks lending process which, over the last few years, has undoubtedly improved. For our investigation, we begin by looking at PAPERBASIS' S.A. historical performance (part I) and conclude by projecting two scenarios of its future liquidity and solvency as crucial indicators in assessing its real financing requirements (part II).

\section{PART I}

The factors that influence the corporate credit decisions of banks can vary from those generally associated with the overall economic environment and the conditions in the borrower's industry ${ }^{2}$ to those that more specifically reflect the circumstances of the applicant company or the strategy of the bank. In this sense, the risk assessment models employed in corporate lending incorporate a score of quantitative and qualitative ${ }^{3}$ measures that produce a credit score for the applicant company. However, in the present study we are not aiming in determining the degree of risk for a given lending relationship (also there is no reference to information about collaterals, personal guarantees or pledged firm's assets - issues that usually considered in the decision process). Our purpose is to investigate why a specific company wishes to borrow (since the reason is usually critical to the type of credit facility offered) and to present a formal way of determining its future borrowing needs. Proposed methodology will be applied with respect to PAPERBASIS S.A. a firm that established in 1989 and specializes in the development and customizing of office equipment.

Paperbasis' financial statements report the historical results of its operations and financial condition (Table 2, 3, 5 - panel A). Management uses this information to run the business while this data provides a critical indicator of the degree of risk in a lending relationship. Objectives of financial analysis include determining not only how a firm performed but also the underlying causes for that financial performance.

In table 5 (Panel A), the cash-flow statements for the years 2003-2004, are constructed to indicate the amount of cash movement associated with every line item on the income statement ${ }^{4}$. How much cash was spent on:

- $\quad$ each year in goods or services for sale (regardless of whether they were actually sold this period)

- $\quad$ operating expenses (even if some of those expenses were incurred last year)

- $\quad$ taxes (regardless of how much the company might report as its accrual obligation)

- $\quad$ fixed assets, long-term investments etc

is established. In reading the cash-flow statement we first focus on net cash income. If net cash income is positive, it means that the company generated enough cash from its normal, core business operations to pay interest expense. If net cash income is negative it means the company did not generate enough cash from internal operations to pay interest expense regardless of the size of the accrual-based net income number. PAPERBASIS did not generate enough

\footnotetext{
${ }^{2}$ Michael Porter (1980) has developed a framework for assessing competitive forces in an industry (namely: threat of entry, intensity of rivalry, pressure from substitute products, bargaining power of buyers/suppliers). These forces condition and are relevant in forming forecasted values for risk factors, for projections and in assessing market risk.

${ }^{3}$ E.g. management style and structure, credit history, competitive positioning e.t.c.

${ }^{4}$ The format of the cash-flow statement displayed in Table 5 is essentially the Uniform Credit Analysis format which is most similar to the direct format prescribed by the accounting profession. The direct format is generally the more useful because it fully integrates the balance sheet and income statement to create a cash-based income statement that lenders can readily use. Nonetheless the indirect format provides some analytical resources that are missing in the direct format.
} 
cash in year 2003 and 2004 to pay interest expense and dividends. Note, however that the deficit of net cash income in 2002 (€ 104.009) and part of it in 2003 (€ 380.111) is due to high dividends distributed (€ 298.800).

Table 4 (Panel A) provides the key ratios for PAPERBASIS from 2002 through 2004. On balance, the ratios over the three-year period indicate a general deterioration in the company's financial position. Its profitability has decreased in terms of both gross and net profit margins. Its leverage did not change substantially but its liquidity, as shown from the quick ratio, has decreased over the time period (0,60 in 2002 to 0,54 in 2004). Further, we see that PAPERBASIS holds relatively larger balances of inventory and accounts receivables (as evidenced from inventory and receivables days respectively) while simultaneously by paying its suppliers earlier (accounts payable days decreased from 162 in 2002 to 129 in 2004) creates a financing gap from its core activities. Nevertheless given the brief analysis above (detailed or/and peer group analysis are beyond the scope of the study), the overall financial condition of the applicant can be characterized satisfactory.

\section{PART II}

In part I, main aspects of a company's historical operations were considered and those operations were viewed against two benchmarks: liquidity and solvency. The historical information gathered and analyzed has implications for the future and in this part the focus shifts to a company's likely future operating performance. Any extension of credit considered today will be repaid from cash generated in the future but since the future is uncertain, one must critically evaluate each possible source of future cash. As an alternative to doing nothing, projections allow a lender to review a range of likely outcomes (one of which may be that the future will be like the past but there could be many others as well), to determine which set of outcomes can be lived with given the company profile and to identify the critical values and how much they may fluctuate before the results become unacceptable.

Concepts are fine, but how are projections actually structured? Projections are critically important to the credit decision process and can be computer-generated easily. It is also possible for someone to construct a group of projected financial data manually even if he will need to spend much more hours. In any case, the first step is understanding how to shape forecast assumptions about a set of critical projection variables - the risk factors. Projections are only good as the underlying assumptions. The decisions regarding the likely future values of the risk factors determine the actual and cash position for the business. Table 1 depicts the (seven) operating risk factors that will provide the key elements in the projected balance sheet, income statement and cash flow of the following casestudy.

Specific attention will be given to shaping the initial values for the aforementioned risk factors which are crucial for the accurate implementation of the projections ${ }^{5}$. Projected values for all other, inter-dependent to those risk factors, accounts could be based on statistical applications (e.g linear regression) upon their historical values or/and on personal intuition driven by recent developments in company's environment.

\section{Case Study}

At this point, we will use an illustrative example so as to apply the proposed methodology for determining the borrowing needs of PAPERBASIS S.A and interpreting the results.

\section{Loan Application}

Assume that PAPERBASIS's working capital line of credit is approaching its renewal date. Mr. Tison- the manager and business owner of the firm-, wants to renew the line at a higher (by 10\%) amount and at better terms. He thinks sales will slightly increase, but in his opinion, the present $€ 500.000$ working capital line should not be

\footnotetext{
${ }^{5}$ Not surprisingly, in practice, it is uncommon that the projected financial statements fully reflect the actual financial statements eventually realized as the time passes. Usually the degree of divergence depends on the time length between the last reporting date and the projected date of financial statements but can also be affected by unexpected events with serious impact to the operations of the company.
} 
necessary for receivables and inventory financing. Further, Mr. Tison indicated that he will not need to spend external funds on new equipment.

\section{Process of Bank Assessment}

Mr. Tison’s request is very typical. Every business owner is interested in making money. The starting point for making money is focusing on revenue, as Tison has done. It is the starting point for virtually every planning or budgeting process, whether highly informal and carried around in the owner's head or very structured and contained in countless papers and reports. Though acknowledged, balance sheet accounts are often an afterthought. In making his request, Mr. Tison did not necessarily comment on his precise expectations about accounts receivable/payable or inventory. He intuitively ignores that even if sales increase his accounts receivables/payables and inventory are likely to decrease and as a consequence (held other parameters constant) borrowing needs to be lower, at least in the shortterm.

In order to assess a loan application it is important to proceed in an orderly manner. First of all if the application is long time after the reporting date a bank should ask for additional financial information or updated firm's financial statements. Additionally, banks usually ask for recent balances of key accounts, such as working capital, reserves, debtors, creditors, other bank loans etc, and comparative list with the previous year levels. Based on these reports and any relative information concerning the company's stated objectives it is possible to complete an initial projection for the basic risk factors ${ }^{6}$.

Obviously, many alternative scenarios and a range of likely outcomes can be produced. For the purposes of this study we are going to develop two alternative scenarios. The first is more opportunistic and hypothesizes an increase in firm's net sales by approximately $5 \%$ while the second assumes a decrease in rate of sales by roughly $5 \%$. Table 1 illustrates the projected values of the major risk factors for the two alternative scenarios. We can then project all the other, generally closely related to risk factors, PAPERBASIS's accounts and balances for 2005.

Absent any recent (interim) company's financial reports one could project these accounts by simply assuming that they all grow according to the sales growth rate ${ }^{7}$. However, as it was already mentioned, there are also some other designs and reasoning that can be used to calculate the amounts of these accounts. In this study, in an attempt to produce more insensitive projected amounts, for each of the two scenarios employed we apply a different design. Specifically, with respect to the first (opportunistic) scenario, we suppose that PAPERBASIS was willing to provide the bank with all necessary information (as it usually happens with the majority of borrowers in real life) and we therefore base our analysis on updated financial data which are contrasted to their last years comparative levels in order to identify the underlying trends (e.g comparison of financial data of July 2005 with those of July 2004). However, we do not add any extra amount of new debt in the projected balance sheet. Regarding the second scenario and assuming that there was not access to PAPERBASIS recent balances and updated financial information, we routinely employ linear regression applicable to all historical values of each specific account. Further, we incorporate an additional amount of debt to allow for the possibility that PAPERBASIS gain access to external financing from another bank. Of course, all assumptions about the risk factors and other accounts could be re-examined and any adjustments that are warranted will be made after thinking more carefully about management objectives and capabilities and the likely impact of the competitive forces on the company's risk factors. In this context one can construct a revised set of projected financial statements that reflect any adjustments made to the initial assumptions.

At this point the task is fairly easy. We simply take all values anticipated thus far and arrange them in proper balance sheet and income statement format (TABLES 2, 3 - PANEL B). We then use the projected balance sheet and income statement for each scenario, along with the actual 2004 balance sheet amounts, to construct the projected 2005 alternative cash flow statements for PAPERBASIS (TABLE 5 - PANEL B).

\footnotetext{
${ }^{6}$ Yet, for a given company, projected values for the basic risk factors (and for any other account is needed) can be calculated on the basis of simply regressing its historical data.

${ }^{7}$ For example: Prepaid expenses and deposits should be tied to operating expenses which are in turn tied to sales. By the same token liabilities, such as accrued expenses, are usually related to sales activity through a direct relationship to operating expenses.
} 
Table 4 - panel B illustrates PAPERBASIS's major projected 2005 financial ratios according to the two scenarios employed. The company in both cases is projected to be more profitable than in previous years. An interesting issue though emerges from the three turnover ratios (accounts receivables days, inventory days, accounts payable days) that generally have major implications for the cash position of the company. These three risk factors are referred to the bibliography as swing factors since small movements in them can result in a significant shift (swing) in the cash position of the company. In the case of PAPERBASIS the contrasting movement of the swing factors in each scenario resulted in the creation of different needs for external financing. More analytically, the general improvement (deterioration) of trading cycle's terms forecasted by the $1^{\text {st }}\left(2^{\text {nd }}\right)$ scenario generates (does not generate) enough cash from internal operations despite the anticipated decrease (increase) in sales.

Note especially that the current assets section of the projected balance sheet includes an account entitled CASH SURPLUS. In effect this is the balancing account. Whatever amount of redundant cash is necessary to make the balance sheet balance shows up in this account. An opposite result would have depicted if the firm was anticipated no to possess sufficient cash to accommodate its 2005 needs. In such a case the current liabilities section of the balance sheet would include (instead of the cash surplus account) another balancing account entitled "additional short-term debt” indicating the projected borrowing needs for the year 2005.

Given the analysis so far the credit decision for PAPERBASIS should not be fairly clear-cut at this point. On the one hand the company is projected not to face liquidity or solvency tests. Furthermore, it seems (by relying more heavily on realization of the $1^{\text {st }}$ scenario) that it will generate enough cash to repay the new debt even in the case of approving a larger amount than that of the current loan request. On the other hand there is no clear evidence about the possible usage of requested funds.

But which is the proper decision? Common wisdom suggests that even if the bank approves an increase in the present line of credit the company will never use this facility (in practice a great number of approved loans remain inactive). In this context, the final decision is marginal and one could argue that acceptance or rejection of the application is basically depending on the invaluable personal judgment of the decision maker and the strategy of the bank.

\section{CONCLUSION}

Projections are a very important tool in any credit decision. Yet, projections can be one of the more difficult areas of financial analysis and credit assessment.

This introductory workbook focused on the interpretation of a mechanical process of actually constructing projected accounts. Forecast assumptions were translated into future income statement, balance sheet values and generated cash flows. In so doing, guidance was provided about the proper approach to setting key forecast assumptions and the mechanics of generating projected figures. Not withstanding the limitations and uncertainties that accompany any projection exercise we relate the results of the projections and analysis to the rationale behind a typical lending decision.

In the (marginal) case of PAPERBASIS S.A., it appears that the lending decision process could possibly proceed even if the company would likely not use the requested additional funds.

Table 1 - Basic Risk Factors

\begin{tabular}{|l|c|c|c|}
\hline & $\mathbf{2 0 0 4}-\mathbf{A c t u a l}$ & $\mathbf{2 0 0 5}-\mathbf{1}^{\text {st }}$ scenario & $\mathbf{2 0 0 5}-\mathbf{2}^{\text {nd }}$ scenario \\
\hline Sales Growth (\%) & 0,63 & $\mathbf{( 5 , 0 9 )}$ & 4,16 \\
\hline Gross Margin (\%) & 10,31 & 11,53 & 11,55 \\
\hline Percentage of Operating Expense & 19,8 & 20,6 & 20,5 \\
\hline Accounts Receivable Days & 73 & 71 & 72 \\
\hline Inventory Days & 114 & 106 & 124 \\
\hline Accounts Payable Days & 129 & 145 & 113 \\
\hline Fixed Asset Spending & 139.226 & 132.780 & 130.633 \\
\hline
\end{tabular}


PAPERBASIS S.A. - BALANCE SHEET (amounts in €)

\begin{tabular}{|c|c|c|c|c|c|}
\hline \multirow[t]{3}{*}{ TABLE 2} & \multicolumn{3}{|c|}{ HISTORICAL DATA } & \multirow{2}{*}{\multicolumn{2}{|c|}{$\begin{array}{l}\text { FUTURE DATA } \\
\text { PANEL B }\end{array}$}} \\
\hline & \multicolumn{3}{|c|}{ PANEL A } & & \\
\hline & $31 / 12 / 2002$ & $31 / 12 / 2003$ & $31 / 12 / 2004$ & $31 / 12 / 2005$ & $31 / 12 / 2005$ \\
\hline \multicolumn{6}{|l|}{ ASSETS } \\
\hline \multicolumn{6}{|l|}{ FOUNDATION EXPENSES } \\
\hline Preliminary expenses & 2.145 & & & & \\
\hline Other formation expenses & 6.449 & & & & \\
\hline Less Depreciation & $(8.594)$ & & & & \\
\hline Net Foundation expenses & - & & & & \\
\hline \multicolumn{6}{|l|}{ FIXED ASSETS } \\
\hline \multicolumn{6}{|l|}{ I. Property, Plant \& Equipment } \\
\hline Land & 89.272 & 172.547 & 172.547 & 176.791 & 228.064 \\
\hline Buildings & 597.592 & 629.079 & 752.358 & 805.485 & 814.442 \\
\hline Machinery \& equipment & 4.584 & 5.434 & 5.911 & 6.483 & 6.637 \\
\hline Transportation equipment & 253.291 & 251.979 & 251.979 & 308.208 & 251.104 \\
\hline Furniture \& Fixtures & 130.818 & 147.855 & 163.325 & 181.933 & 176.506 \\
\hline $\begin{array}{l}\text { Payments on account \& tangible assets in course of } \\
\text { construction }\end{array}$ & 5.001 & - & - & & \\
\hline Gross Fixed Assets & 1.080 .558 & 1.206 .894 & 1.346 .120 & 1.478 .900 & 1.476 .753 \\
\hline Less Accumulated Depreciation & (585.934) & $(657.087)$ & (727.098) & $(815.380)$ & $(797.871)$ \\
\hline Net Fixed Assets & 494.624 & 549.807 & 619.022 & 663.520 & 678.882 \\
\hline \multicolumn{6}{|l|}{ II. Long-Term Assets } \\
\hline Investments in other Companies & 11.589 & 11.589 & - & $=$ & - \\
\hline Other long-term assets & 2.562 & 2.562 & - & - & - \\
\hline Total Fixed \& Long-Term Assets & 508.775 & 563.958 & 619.022 & 663.520 & 678.882 \\
\hline \multicolumn{6}{|l|}{ CURRENT ASSETS } \\
\hline Inventory & 1.343 .051 & 1.542 .829 & 1.641 .488 & 1.404 .757 & 1.807 .560 \\
\hline Debtors & 454.784 & 486.486 & 529.199 & 476.734 & 564.571 \\
\hline Accounts Receivable & 938.379 & 909.993 & 982.380 & 917.745 & 987.585 \\
\hline Advance Payments & 130.551 & 156.843 & 158.882 & 158.882 & 177.090 \\
\hline Cash & 47.109 & 138.170 & 44.638 & 74.035 & 74.168 \\
\hline \multirow[t]{2}{*}{ Bank deposits } & 300.980 & 233.092 & 60.532 & 191.467 & - \\
\hline & & & & $\begin{array}{c}211.797 \\
\text { CASH } \\
\text { SURPLUS }\end{array}$ & $\begin{array}{c}2.811 \\
\text { CASH } \\
\text { SURPLUS }\end{array}$ \\
\hline Total Current Assets & 3.214 .854 & 3.467 .413 & 3.417 .119 & 3.435 .417 & 3.613 .785 \\
\hline TOTAL ASSETS & 3.709 .478 & 4.017.220 & 4.036.141 & 4.098.937 & 4.292 .667 \\
\hline \multicolumn{6}{|l|}{ LIABILITIES \& SHAREHOLDERS’ EQUITY } \\
\hline Shareholders' Capital & 333.089 & 437.742 & 437.742 & 437.742 & 507.511 \\
\hline Revaluation Assets Reserve & 57 & 57 & 57 & 57 & -2 \\
\hline Legal Reserves & 73.300 & 145.752 & 165.701 & 165.701 & 171.697 \\
\hline Tax free Reserves & 18.278 & 18.278 & 18.278 & 18.278 & 18.278 \\
\hline Total Capital and Reserves & 424.724 & 601.828 & 621.777 & 621.777 & 697.486 \\
\hline \multicolumn{6}{|l|}{ Provisions for Liabilities \& Charges } \\
\hline Other Provisions & 143.654 & 156.134 & 156.134 & 156.134 & 164.454 \\
\hline \multicolumn{6}{|l|}{ LIABILITIES } \\
\hline \multicolumn{6}{|l|}{ Short-Term liabilities } \\
\hline Suppliers & 394.296 & 437.731 & 412.991 & 386.951 & 433.701 \\
\hline Notes Payable & 1.879 .452 & 1.616 .487 & 1.447 .621 & 1.536 .457 & 1.216 .022 \\
\hline Bank Loans & 352.154 & 442.153 & 703.399 & 703.399 & $937.865 * * *$ \\
\hline Taxes Payable & 178.628 & 287.135 & 223.055 & 223.055 & 274.033 \\
\hline Social Security Contributions & 27.931 & 31.567 & 34.564 & 34.564 & 37.987 \\
\hline Dividends Payable & 179.868 & 298.800 & 298.800 & 298.800 & 378.088 \\
\hline Misc. Creditors & 88.041 & 105.000 & 97.000 & 97.000 & 105.639 \\
\hline Other Current liabilities & 40.730 & 40.385 & 40.800 & $40.800^{-}$ & 47.392 \\
\hline Total liabilities & 3.141 .100 & 3.259 .258 & 3.258 .230 & 3.321 .026 & 3.430 .727 \\
\hline Total Liabilities \& Shareholders' Equity & 3.709 .478 & 4.017.220 & 4.036.141 & 4.098.937 & 4.292 .667 \\
\hline
\end{tabular}


* calculations of amounts were based on recent (as of July 2005) financial data provided by firm

** calculations of amounts were based on regressing past values (from years 2002,2003,2004) of each account

*** assuming additional external financing

PAPERBASIS S.A. - STATEMENT OF INCOME AND RETAINED EARNINGS

(amounts in €)

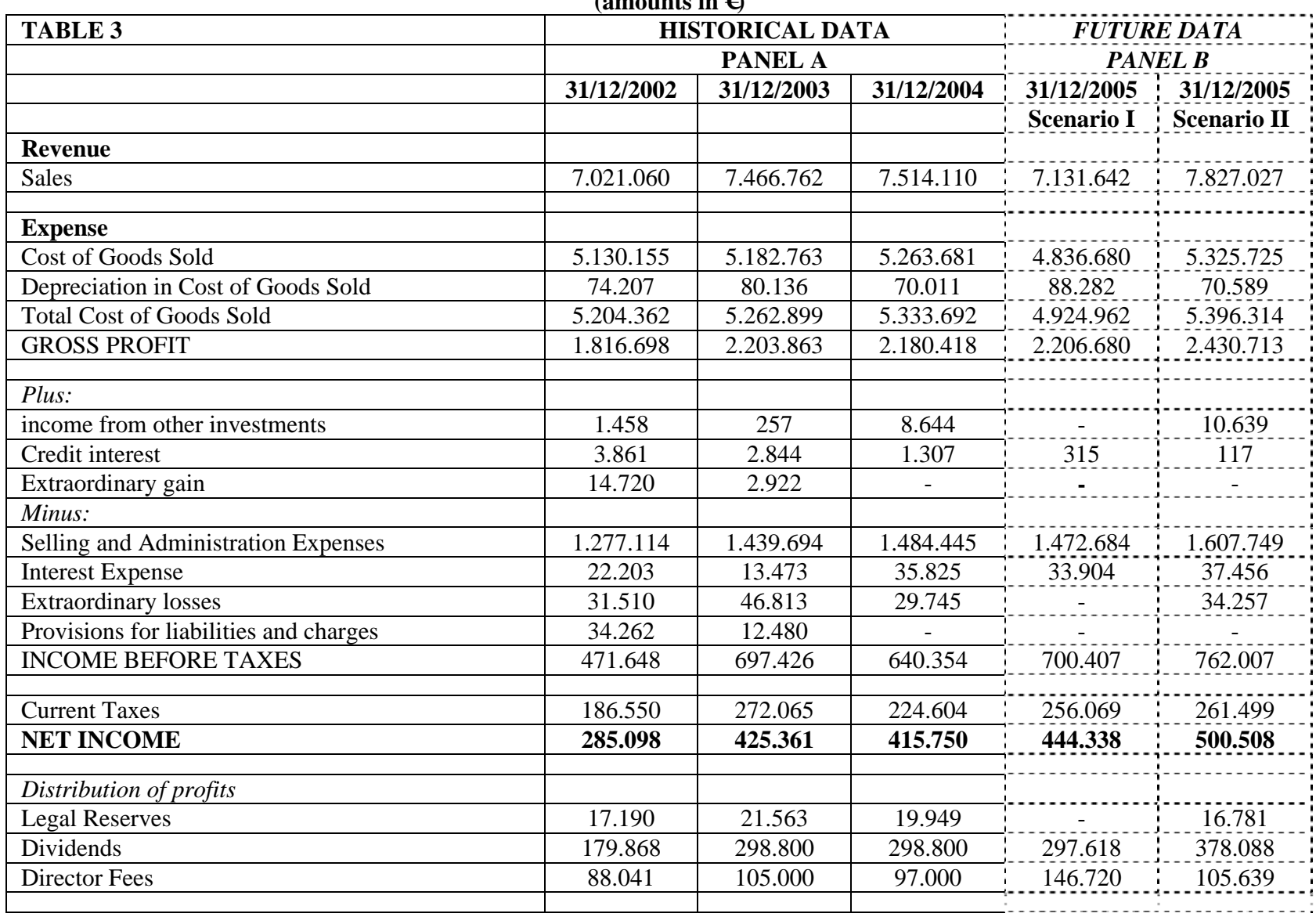

PAPERBASIS S.A. - RATIO ANALYSIS

\begin{tabular}{|l|c|c|c|}
\hline TABLE 4 & \multicolumn{3}{|c|}{ HISTORICAL DATA } \\
\hline & \multicolumn{3}{|c|}{ PANEL A } \\
\hline & $\mathbf{3 1 / 1 2 / 2 0 0 2}$ & $\mathbf{3 1 / 1 2 / 2 0 0 3}$ & $\mathbf{3 1 / 1 2 / 2 0 0 4}$ \\
\hline Sales Growth & & & \\
\hline Gross Margin & & & \\
\hline Net Profit Margin before Taxes & & 6,35 & 0,63 \\
\hline EBITDA/Interest expenses & 8,76 & 11,31 & 10,31 \\
\hline Total Liabilities/EBITDA & 6,72 & 9,34 & 8,52 \\
\hline Total Liabilities/Net Worth & 27,71 & 62,69 & 21,62 \\
\hline Accounts Receivables Days & 5,11 & 3,86 & 4,21 \\
\hline Inventory Days & 5,53 & 4,30 & 4,19 \\
\hline Accounts Payable Days & 72 & 68 & 73 \\
\hline Quick Ratio & 96 & 109 & 114 \\
\hline Working Capital (\% of Sales) & 162 & 145 & 129 \\
\hline
\end{tabular}




\begin{tabular}{|c|c|c|c|c|}
\hline \multicolumn{3}{|c|}{ PAPERBASIS S.A. - CASH FLOW STATEMENT (amounts in €) } & \multirow{2}{*}{\multicolumn{2}{|c|}{ FUTURE DATA }} \\
\hline \multirow[t]{4}{*}{ TABLE 5} & \multicolumn{2}{|c|}{ HISTORICAL DATA } & & \\
\hline & \multicolumn{2}{|c|}{ PANEL A } & \multicolumn{2}{|c|}{ PANELB } \\
\hline & $31 / 12 / 2003$ & $31 / 12 / 2004$ & $31 / 12 / 2005$ & $31 / 12 / 2005$ \\
\hline & & & Scenario I & Scenario II \\
\hline Sales & 7.466 .762 & 7.514 .110 & 7.131 .642 & 7.827 .027 \\
\hline Change in Trade Accounts/Notes Receivable & $(3.316)$ & $(115.100)$ & 117.100 & $(40.577)$ \\
\hline Cash Collected From Sales & 7.463 .446 & 7.399 .010 & 7.248 .742 & 7.786 .450 \\
\hline Cost of Sales & (5.262.899) & $(5.333 .692)$ & $(4.924 .962)$ & $(5.396 .314)$ \\
\hline Minus : Depreciation included in Cost of Sales & 80.136 & 70.011 & 88.282 & 70.589 \\
\hline Change in Inventories & $(199.778)$ & (98.659) & 236.731 & $(166.072)$ \\
\hline Change in Accounts/Notes Payable & $(219.530)$ & $(193.606)$ & 62.796 & $(210.889)$ \\
\hline Cash Paid to Suppliers & $(5.602 .071)$ & $(5.555 .946)$ & $(4.537 .153)$ & $(5.702 .686)$ \\
\hline Cash from Trading Activities & 1.861 .375 & 1.843 .064 & 2.711 .589 & 2.083 .764 \\
\hline Cash Paid for Operating Costs & (1.538.603) & $(1.578 .448)$ & $(1.619 .404)$ & $(1.701 .645)$ \\
\hline Cash After Operations & 322.372 & 264.616 & 1.092 .185 & 382.119 \\
\hline Change in income Taxes Payable & 81.023 & $(64.080)$ & & 41.817 \\
\hline Taxes - Paid in Cash & $(244.581)$ & $(224.604)$ & $(256.069)$ & $(262.178)$ \\
\hline Provisions for liabilities and charges & $(12.480)$ & - & -1 & - \\
\hline Extraordinary results & $(43.891)$ & $(29.745)$ & - & $(34.257)$ \\
\hline Credit interest and income from other investments & 3.101 & 9.951 & 315 & 10.756 \\
\hline Change in other non operating accounts & $(16.612)$ & $(1.624)$ & & $(11.616)$ \\
\hline Net Cash After Operations & 89.332 & (45.486) & 836.431 & 126.641 \\
\hline Interest Expense & (13.473) & $(35.825)$ & $(33.904)$ & $(37.456)$ \\
\hline Dividends & $(298.800)$ & $(298.800)$ & $(297.618)$ & $(378.088)$ \\
\hline Change in accrued dividends & 118.932 & - & - & 79.288 \\
\hline Cash after Debt Amortization & $(104.009)$ & $(380.111)$ & 504.909 & $(209.615)$ \\
\hline Change in Land & $(83.275)$ & - & $(4.244)$ & $(55.517)$ \\
\hline Change in Buildings & $(31.487)$ & $(123.279)$ & $(53.127)$ & $(62.084)$ \\
\hline Change in Machinery \& Equipment & $(850)$ & $(477)$ & $(572)$ & $(726)$ \\
\hline Change in Transportation equipment & 1.312 & - & $(56.229)$ & 875 \\
\hline Change in Furniture \& Fixtures & $(12.036)$ & $(15.470)$ & $(18.608)$ & $(13.741)$ \\
\hline Depreciation/Amortization expense & $(80.136)$ & $(70.011)$ & $(88.282)$ & $(70.589)$ \\
\hline Cash Paid for Plant and Equipment & $(135.319)$ & $(139.226)$ & $(132.780)$ & $(130.449)$ \\
\hline Cash surplus before financing & $(239.328)$ & $(519.337)$ & 372.129 & $(340.064)$ \\
\hline Change in short-term debt & 89.999 & 261.246 & & 234.466 \\
\hline Change in capital, reserves and Misc. creditors & 172.498 & $(8.000)$ & - & 77.406 \\
\hline Total External Financing & 262.497 & 253.246 & 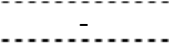 & 311.872 \\
\hline Net Cash surplus & 23.169 & $(266.091)$ & 372.129 & $(28.192)$ \\
\hline Initial Deposits and cash & 348.089 & 371.262 & 105.170 & 105.170 \\
\hline Year-end Deposits and cash & 371.258 & 105.170 & 477.299 & 76.979 \\
\hline unexplained difference & 4 & $(1)$ & & 1 \\
\hline
\end{tabular}




\section{REFERENCES}

1. Barnhill, T.M. Jnr., and W.F. Maxwell, 2002, Modelling Correlated Interest Rate, Spread Risk, and Credit Risk for Fixed Income Portfolios, Journal of Banking and Finance, v26, 347-374

2. Crouhy, M., D. Galai, and R. Mark, 2001, “Prototype Risk Rating System”, Journal of Banking and Finance, v25, 47-95.

3. Duffee, G.R., and C. Zhou, 1999, Credit Derivatives in Banking: Useful Tools for Managing Risk?, Research Program in Finance Working Papers, Berkeley: University of California Internal Revenue Services (1997), Statistics of Income, US Treasury department, Washington, D.C.

4. Jarrow, R.A., and F. Yu, 2001, Counterparty Risk and the Pricing of Defautable Securities, Journal of Finance, v56, 1765-1799

5. Longstaff, F.A., and E.F. Schwartz, 1995, A Simple Approach to Valuing Risky Fixed and Floating Rate Debt, Journal of Finance, v50, 789-819.

6. Merton, R.C., 1974, On the Pricing of Corporate Debt: The Risk Structure of Interest Rates, Journal of Finance, June, 449-470.

7. Moody's KMV, 2002, Risk Management Services Inc.

8. Porter, M. (1980). Competitive Strategy: Techniques for Analyzing Industries and Competitors, Free Press. 
